\title{
Pengaruh Konsumsi Madu terhadap Lama Persalinan Kala I dan Kala II
}

\section{Effect of Honey Consumption on Period I and Stage II Labor}

\author{
Rosmadewi $^{1}$, Ranny Septiani ${ }^{2}$ \\ Jurusan Kebidanan, Politeknik Kesehatan Tanjung Karang, Indonesia
}

\begin{tabular}{l} 
ARTICLE INFO \\
\hline Article history \\
Received date \\
18 Mar 2021 \\
Revised date \\
12 Apr 2021 \\
Accepted date \\
14 Apr 2021 \\
\hline
\end{tabular}

Keywords:

Honey;

Labor progress;

Pregnant women.

\section{Kata kunci:}

Madu;

Kemajuan persalinan;

Ibu hamil

\begin{abstract}
ABSTRAK
The proportion of incidence of prolonged labor is 4,3 and is the second order of birth disorders or complications after premature rupture of membranes. The problem in this study was that $9 \%$ of women who gave birth were referred to the hospital because they experienced prolonged labor/labor was not advanced. This study aims to determine the effect of honey consumption on stage I and stage II labor duration in third-trimester multigravida pregnant women at PMB Karang Anyar Community Health Center, South Lampung Regency in 2019. This type of research is a quantitative (analytical) research method using a true experimental design with a post-test design only control group design. The subjects of the study were 90 third trimester multigravida, pregnant women. Data collection uses primary data. Univariate data analysis using percentages and bivariate analysis using chi-square. The results showed that there was an effect of giving honey consumption to third-trimester multigravida pregnant women on the first stage of labor with a p-value of 0,05 and there was an effect on the duration of labor in the second stage with a p-value of 0,02 . Midwives as service providers to pregnant women and women who give birth advise mothers to consume honey 2-3 tablespoons 2 times a day from 34 weeks of gestation for good uterine contractions and increase the strength of the mother to push during the labor process.
\end{abstract}

Proporsi kejadian partus lama adalah 4,3 dan merupakan urutan ke 2 jenis gangguan atau komplikasi persalinan setelah ketuban pecah dini. Masalah dalam penelitian ini didapatkan 9\% ibu bersalin yang dirujuk ke Rumah Sakit karena mengalami partus lama/partus tak maju. Penelitian ini bertujuan untuk mengetahui pengaruh konsumsi madu terhadap lama persalinan kala I dan kala II pada ibu hamil multigravida trimester III di PMB wilayah Puskesmas Karang Anyar Kabupaten Lampung Selatan Tahun 2019. Jenis penelitian ini adalah metode penelitian kuantitatif (analitik) dengan menggunakan desain true eksperimen dengan rancangan post-test only control group design. Subjek penelitian adalah ibu hamil multigravida trimester III sejumlah 90 orang. Pengumpulan data menggunakan data primer. Analisa data univariat menggunakan persentase dan analisa bivariat menggunakan chi square. Hasil penelitian didapatkan ada pengaruh pemberian konsumsi madu pada ibu hamil multigravida trimester III terhadap lama persalinan kala I dengan $p$-value 0,05 dan ada pengaruh terhadap lama persalinan kala II dengan $p$-value 0,02. Bidan sebagai pemberi pelayanan kepada ibu hamil dan ibu bersalin menganjurkan kepada ibu untuk mengkonsumsi madu 2-3 sendok makan 2 kali dalam sehari sejak usia kehamilan 34 minggu untuk kontraksi uterus baik dan menambah kekuatan mengejan ibu pada proses persalinan.

Corresponding Author:

Rosmadewi

Jurusan Kebidanan, Politeknik Kesehatan Tanjung Karang, Indonesia

Email: ros29madewi@gmail.com

\section{PENDAHULUAN}

Setiap hari di Indonesia ada 38 ibu yang meninggal akibat penyakit/komplikasi terkait kehamilan dan persalinan. (WHO, 2019). Angka kematian ibu di Indonesia pada tahun 2019 yaitu 306/100.000 KH. Angka ini menurun bila dibandingkan pada SDKI tahun 2012 yaitu
359/100.000 KH (Badan Pusat Statistik, 2017). Penyebab utama kematian ibu kira-kira $75 \%$ disebabkan perdarahan pasca salin, infeksi pasca salin, pre eclampsia/ecklampsia, partus lama/macet dan aborsi yang tidak aman. Kematian maternal terjadi paling banyak (34\%) pada periode persalinan dan 24 jam pertama pasca persalinan. 
Partus lama merupakan penyulit atau komplikasi yang terjadi pada periode persalinan. Partus lama merupakan salah satu penyebab kematian ibu dan janin. Partus lama dapat menyebabkan infeksi, kehabisan tenaga, dehidrasi dan perdarahan post partum. Pada janin akan terjadi infeksi, cedera dan asfiksia yang dapat meningkatkan kematian bayi (Kusumahati, 2010). Insiden partus lama menurut penelitian $2,8-4,9$ persen. Faktor-faktor yang mempengaruhi lamanya persalinan meliputi faktor ibu, faktor janin dan faktor jalan lahir. Faktor ibu meliputi usia, his dan kekuatan mengejan ibu serta paritas.

Kemajuan persalinan pada kala I fase aktif merupakan saat yang paling melelahkan, berat, dan kebanyakan ibu mulai merasakan sakit atau nyeri, dalam fase ini kebanyakan ibu merasakan sakit yang hebat karena kegiatan rahim mulai lebih aktif. Pada fase ini, dibutuhkan kontraksi (power) yang adekuat untuk dapat memulai persalinan. Melemahnya kontraksi rahim atau kontraksi inadekuat ini merupakan penyebab terbanyak terjadinya partus lama (Suroso, 2016). Akibat dari partus lama ini juga dapat menyebabkan terjadinya perdarahan pada kala III dan kala IV.

Pada persalinan kala II juga dibutuhkan dorongan yang kuat untuk melahirkan bayinya (Power) dalam bentuk his yang kekuatannya 5 kali dalam 10 menit dan lamanya lebih dari 40 detik serta kekuatan mengejan ibu. Kedua hal tersebut sangat tergantung dari status nutrisi selama hamil dan makanan yang dikonsumsi selama dalam proses persalinan. Ibu bersalin pada saat melahirkan sebaiknya diberikan minuman yang mengandung gula antara lain teh manis atau air madu hangat agar proses pembentukan tenaga segera terwujud karena air teh manis dan air madu hangat langsung diserap dan masuk pembuluh darah.

Faktor utama yang menyebabkan terjadinya partus lama terutama pada persalinan kala 1 dan kala 2 disebabkan karena his atau kontraksi yang kurang baik. His merupakan hal yang sangat dominan diperlukan pada proses persalinan agar persalinan dapat berlangsung dengan normal. Waktu yang diperlukan untuk persalinan normal pada kala 1 untuk primipara berlangsung sekitar 12 jam dan untuk multipara berlangsung sekitar 7 jam sejak masuk ke dalam fase aktif. His dan kekuatan mengejan ibu yang baik sangat tergantung terhadap nutrisi yang dikonsumsi ibu selama hamil. Salah satu nutrisi yang baik dikonsumsi ibu pada masa hamil adalah madu karena madu merupakan suplemen penambah tenaga dan ketahan diri selama mengandung dan pada saat menjelang masa kelahiran bayi.

Perempuan hamil yang akan melahirkan sangat membutuhkan minuman dan makanan yang kaya akan unsur gula, hal ini karena banyaknya kontraksi otot-otot rahim ketika akan mengeluarkan bayi, terlebih lagi apabila hal itu membutuhkan waktu yang lama. Kandungan gula, vitamin B1, dan zat besi sangat membantu untuk mengontrol laju gerak rahim dan menambah masa sistole (kontraksi jantung ketika darah dipompa ke pembuluh nadi).

Madu alami pada umumnya terbuat dari nectar yang didalamnya terdapat cairan manis yang terdapat dalam mahkota bunga yang dapat diserap oleh lebah atau tawon, yang kemudian dikumpulkan dan disimpan didalam sarangnya untuk diolah menjadi bahan persediaan makanan utama bagi mereka.(Purbaya, 2007). Pada madu terdapat pollen yang merupakan makanan pokok dari lebah. Pollen bermanfaat untuk meningkatkan imunitas tubuh, memacu vitalitas dan kesehatan tubuh. Pollen juga sebagai antioksidan, antibakteri dan mencegah pertumbuhan kanker. Pollen direkomendasikan sebagai makanan untuk menanggulangi stress dan kelelahan (Ihsan, 2011).

Istilah tonik biasanya digunakan sebagai efek yang memacu dan memperkuat semua sistem organ serta menstimulasi perbaikan sel-sel tonus otot. Obat-obat yang menyebabkan efek tonik tersebut digolongkan sebagai tonikum. Efek tonik ini dapat terjadi karena efek stimulan yang dilakukan terhadap sistem syaraf pusat (Sambodo, 2009).

Suranto (2004) menyatakan bahwa madu berkhasiat untuk menghasilkan energi, meningkatkan daya tahan tubuh dan meningkatkan stamina. Madu juga mengandung unsur makanan yang luar biasa walaupun kadarnya kecil, sehingga bisa digunakan sebagai tonik alami (Baskhara, 2008). Manfaat madu bukan hanya sekedar untuk kesehatan karena pada dasarnya madu merupakan bahan makanan yang populer didunia kuliner sebagai pemanis atau pengental.

Kandungan yang terdapat di dalam madu berupa senyawa fruktosa $(38,5 \%)$ dan glukosa $(3,10 \%)$, selain itu ada pula karbohidrat seperti Maltosa, sukrosa dan karbohidrat kompleks lainnya. Kandungan yang lainnya pada madu berupa anti-oksidan meskipun hanya sedikit yakni dari senyawa Chrysin, Pinobanksim, vitamin $\mathrm{C}$, katalase, Pinocembrin. Selain itu juga madu mengandung pollen yang berasal dari makanan lebah yang mengandung vitamin, mineral, protein, asam lemak serta zat penting 
lainnya yang dapat menunjang energi didalam tubuh untuk menambah kontraksi uterus.

Kandungan glukosa pada madu sekitar $75 \%$, glukosa adalah gula inti yang mudah diserap dan disimpan didalam tubuh. Setelah diserap, ia bisa langsung menuju kehati, sehingga berubah menjadi glukogeen yang terus disimpan hingga kapan dibutuhkan. Ketika tubuh akan menggunakannya maka ia akan kembali ke asalnya (berwujud glukosa) yang mengalir bersaa darah, untuk kemudian digunakan sebagai daya penggerak dalam otot.

Ibu hamil sangat disarankan untuk mengkonsumsi madu dalam rangka untuk menambah tenaga karena ibu hamil butuh tenaga ekstra, daya tahan tubuh ekstra dan juga butuh nutrisi yang lebih untuk janinnya. Selain itu juga, madu merupakan bahan alami yang sangat baik untuk kesehatan tubuh. Adapun manfaat madu bagi ibu hamil antara lain menambah tenaga, memperkuat daya tahan tubuh selama kehamilan, meningkatkan nafsu makan, memudahkan buang air besar, membantu janin tumbuh dan berkembang dengan sehat, menguatkan janin, mengurangi rasa mual dan mencegah ibu hamil terserang berbagai penyakit.

Manfaat madu bagi ibu hamil yang menjelang persalinan terutama berkaitan dengan menambah tenaga yang sangat berperan dalam kekuatan kontraksi (his) yang sangat diperlukan dalam proses persalinan. Pada proses persalinan diperlukan tenaga terutama his untuk mendorong janin agar dapat membantu pembukaan jalan lahir sehingga proses persalinan dapat berlangsung secara normal.

Menurut data WHO, sebanyak 99\% kematian ibu akibat masalah persalinan atau kelahiran terjadi di negara-negara berkembang (WHO, 2019). Partus lama rata-rata di dunia menyebabkan kematian ibu sebesar $8 \%$ dan di Indonesia sebesar $9 \%$. Menurut Profil Kesehatan Provinsi Lampung tahun 2016. Kasus kematian di Propinsi Lampung pada tahun 2016 sebanyak 142 kasus yang penyebabnya antara lain perdarahan sebanyak 45 kasus, pre eklampsi/eklampsi sebanyak 41 kasus, infeksi 1 kasus, gangguan sistem peredaran darah sebanyak 8 kasus, dan lain-lain sebanyak 45 kasus termasuk didalamnya yang disebabkan oleh partus lama. (Dinas Kesehatan Provinsi Lampung, 2016; 2017).

Berdasarkan Profil Dinas Kesehatan Kabupaten Lampung Selatan, kasus kematian ibu di Kabupaten Lampung Selatan pada tahun 2017 sebesar 52,68 per $100.000 \mathrm{KH}$ (11 kasus). Penyebab kematian ibu pada tahun 2017 berdasarkan hasil Audit Maternal Perinatal
(AMP) adalah pendarahan $81,81 \%$ (9 kasus), eklampsia 9,09\% (1 kasus) dan Emboli Air Ketuban 9,09\% (1 kasus), penyebaran kasus kematian ibu pada tahun 2017 terdapat di wilayah kerja Puskesmas RI Rajabasa (2 kasus), Puskesmas RI Katibung, Puskesmas RI Penengahan, Puskesmas Natar, Puskesmas Way Sulan, Puskesmas Tanjung Agung, Puskesmas Hajimena, Puskesmas Way Panji, Puskesmas Way Urang, Puskesmas Karang Anyar, dengan masing-masing 1 kasus.

Berdasarkan studi pendahuluan pada praktik mandiri bidan di wilayah Puskesmas Karang Anyar, pada bulan Januari-Desember 2018 didapatkan ibu bersalin yang dirujuk ke Rumah Sakit karena mengalami kala I memanjang sebanyak 9\% (12 orang) dari 126 persalinan, yang terdiri dari primipara 3 orang dan multipara 9 orang.

Atas dasar data yang diperoleh, peneliti tertarik untuk melakukan penelitian untuk mengetahui pengaruh konsumsi madu terhadap lama persalinan kala I dan kala II pada ibu hamil multigravida trimester III di PMB wilayah Puskesmas Karang Anyar Kabupaten Lampung Selatan Tahun 2019.

\section{METODE}

Penelitian ini menggunakan metode penelitian kuantitatif (analitik) dengan desain true eksperimen dengan rancangan post-test only control group design. Populasi dalam penelitian ini ibu hamil usia kehamilan 34 - 37 minggu yang akan melahirkan di PMB Wilayah Puskesmas Karang Anyar Kabupaten Lampung Selatan tahun 2019, yang berjumlah 98 orang. Sampel yang digunakan dalam penelitian sebanyak 60 orang yang terdiri dari 30 orang diberi konsumsi madu dan 30 orang sebagai kontrol tanpa diberikan konsumsi madu.. Pengambilan sampel dengan menggunakan tekhnik Simple Random Samplin deangan cara diundi.

Kriteria inklusi: (a) Ibu hamil multipara yang sehat dan tidak memiliki komplikasi; (b) Ibu hamil bersedia untuk mengkonsumsi madu setiap hari; (c). Ukuran tinggi fundus uteri kurang dari $40 \mathrm{~cm}$ dan; (d). Umur kehamilan mulai dari 35 minggu, (e) Usia ibu hamil antara 20-35 tahun. Sedangkan kriteria ekslusi: (a) Ibu hamil primipara dan grande multipara; (b) Ibu hamil tidak bersedia jadi responden

Data yang dikumpulkan menggunakan data primer. Pemberian madu pada ibu hamil 2-3 sendok makan 2 kali dalam sehari. Berhubung variabel penelitiannya berupa katagorik maka 
jenis uji yang dipilih adalah uji non parametrik dan analisa bivariat dalam penelitian ini dengan menggunakan chi-square. dengan tingkat kemaknaan $95 \%$ ( $p$-value $<\alpha=0,05$ ). Ho ditolak jika $p$-value $\leq 0,05$ dan Ho gagal ditolak jika $p$ value $\geq 0,05$ (Hidayat, 2007).

Penelitian ini telah mendapatkan persetujuan etik dengan Nomor 256/EA/KEPKTJK/IX/2019 oleh Komisi Etik Penelitian Politeknik Kesehatan Tanjung Karang.

\section{HASIL}

Tabel 1. Distribusi Responden Berdasarkan Lama Persalinan Kala I

\begin{tabular}{lcccc}
\hline \multirow{2}{*}{ Konsumsi } & \multicolumn{3}{c}{ Lama Persalinan Kala I } \\
\cline { 2 - 5 } & \multicolumn{2}{c}{$\leq \mathbf{5}$ Jam } & \multicolumn{2}{c}{$>$ Jam } \\
\cline { 2 - 5 } & $\mathbf{n}$ & $\mathbf{\%}$ & $\mathbf{n}$ & $\boldsymbol{\%}$ \\
\hline Madu & 9 & 30 & 21 & 70 \\
Tidak konsumsi madu & 3 & 10 & 27 & 90 \\
\hline
\end{tabular}

Berdasarkan tabel 1, responden yang konsumsi madu lama persalinan kala $\mathrm{I} \leq 5 \mathrm{Jam}$ sebesar $30 \%$, sedangkan yang tidak konsumsi madu sebesar $10 \%$.

Tabel 2. Distribusi Responden Berdasarkan Lama Persalinan Kala II

\begin{tabular}{lcccc}
\hline \multirow{2}{*}{ Konsumsi } & \multicolumn{3}{c}{ Lama Persalinan Kala II } \\
\cline { 2 - 5 } & \multicolumn{3}{c}{$\leq \mathbf{3 0}$ menit } & \multicolumn{2}{c}{$>$ 30 menit } \\
\cline { 2 - 5 } & $\mathbf{n}$ & $\boldsymbol{\%}$ & n & \% \\
\hline Madu & 21 & 70 & 9 & 30 \\
Tidak konsumsi madu & 12 & 40 & 18 & 60 \\
\hline
\end{tabular}

Berdasarkan tabel 2, responden yang konsumsi madu lama persalinan kala II $\leq 30$ menit sebesar $70 \%$, sedangkan yang tidak konsumsi madu sebesar $40 \%$.

Tabel 3. Pengaruh Konsumsi Madu Pada Ibu Hamil Multigravida Trimester III Terhadap Lama Persalinan Kala I.

\begin{tabular}{|c|c|c|c|c|c|c|}
\hline \multirow{2}{*}{ Konsumsi } & \multicolumn{4}{|c|}{ Lama Persalinan Kala I } & \multirow{2}{*}{ Jumlah } & \multirow{2}{*}{ p-value } \\
\hline & \multicolumn{2}{|c|}{$\leq 5 \mathrm{Jam}$} & \multicolumn{2}{|c|}{$>5$ Jam } & & \\
\hline Madu & 9 & $30 \%$ & 21 & $70 \%$ & 30 & \\
\hline Tidak konsumsi madu & 3 & $10 \%$ & 27 & $90 \%$ & 30 & 0,05 \\
\hline Jumlah & 12 & $20 \%$ & 48 & $80 \%$ & 60 & \\
\hline
\end{tabular}

Berdasarkan tabel 3, dari 30 orang responden yang konsumsi madu, lamanya persalinan kala I kurang dari 5 jam sejumlah $30 \%$, sedangkan yang tidak konsumsi madu didapatkan lamanya persalinan kala I kurang dari 5 jam sejumlah $10 \%$. Pada hasil uji Chi Square, didapatkan $p$ value $=0,05 \leq \alpha=0,05$ yang artinya ada pengaruh pemberian konsumsi madu pada ibu hamil multigravida trimester III terhadap lama persalinan kala I. Hal ini menggambarkan bahwa konsumsi madu pada ibu hamil multigravida sejak usia kehamilan trimester III dapat mengurangi lamanya persalinan kala I.

\section{Tabel 4. Pengaruh Konsumsi Madu Pada Ibu Hamil Multigravida Trimester III Terhadap} Lama Persalinan Kala II.

\begin{tabular}{lrrrrrr}
\hline \multirow{2}{*}{ Konsumsi } & \multicolumn{3}{c}{ Lama Persalinan Kala II } & & \\
\cline { 2 - 5 } & $\mathbf{3}$ & $\mathbf{3 0}$ menit & $\mathbf{> 3 0}$ menit & Jumlah & $\boldsymbol{p}$-value \\
\hline Madu & 21 & $70 \%$ & 9 & $30 \%$ & 30 & \\
Tidak konsumsi madu & 12 & $40 \%$ & 18 & $60 \%$ & 30 & 0,02 \\
Jumlah & 33 & $55 \%$ & 27 & $45 \%$ & 60 & \\
\hline
\end{tabular}

Berdasarkan tabel 4, dari 30 orang responden yang konsumsi madu, lamanya persalinan kala II kurang dari 30 menit sejumlah $70 \%$, sedangkan yang tidak konsumsi madu didapatkan lamanya persalinan kala II kurang dari 30 menit sejumlah $40 \%$. Pada hasil uji chisquare, didapatkan $p$-value $=0,02 \leq \alpha=0,05$ yang artinya ada pengaruh pemberian konsumsi madu pada ibu hamil trimester III terhadap lama persalinan kala II. Hal ini menggambarkan bahwa konsumsi madu semenjak usia kehamilan trimester III dapat mengurangi lamanya persalinan kala II.

\section{PEMBAHASAN}

Pengaruh Pemberian Madu terhadap Lama Persalinan Kala I

Berdasarkan hasil penelitian didapatkan ada pengaruh pemberian konsumsi madu pada 
ibu hamil multigravida trimester III terhadap lama persalinan kala I.

Hal ini mendukung hasil penelitian Zuliyanti (2012) dan peneitian Isriani (2017), yang penelitian keduanya menyatakan bahwa pemberian susu dan madu dapat berpengaruh terhadap lamanya persalinan kala I dan kala II. Pada penelitian Zuliyanti (2012) melakukan penelitian dengan memberikan susu dan madu pada ibu bersalin terhadap lamanya kala I dan kala II, dengan hasil ada pengaruh pemberian susu dan madu terhadap lamanya kala II dengan $p$-value 0,001. Sedangkan penelitian Popy Isriani melakukan penelitian dengan memberikan kacang hijau dan madu terhadap lamanya kala II dengan p-value 0,000. Sedangkan peneliti melakukan penelitian hanya dengan memberikan madu saja terhadap lamanya persalinan kala I dan kala II dan pengaruhnya tidak terlalu signifikan terhadap lamanya persalinan kala I dengan $p$ value 0,05 dan lamanya persalinan kala II dengan p-value 0,02 .

Berdasarkan hasil penelitian bahwa pemberian madu dapat mempengaruhi kekuatan kontraksi uterus. Namun berdasarkan hasil penelitian yang dilakukan oleh Zuliyanti (2012) bahwa madu lebih signifikan dalam meningkatan kontraksi uterus bila pemberian madu ditambahkan susu. Sedangkan hasil penelitian yang dilakukan bahwa Isriani (2017) bahwa madu lebih signifikan dalam meningkatan kontraksi uterus bila pemberian madu ditambahkan kacang hijau.

Pada proses persalinan kala I yang sangat berperan dalam kemajuan persalinan adalah faktor his atau kontraksi uterus. Adanya kontraksi uterus secara alamiah dipengaruhi oleh hormon oksitosin. Selain karena pengaruh hormon, diperlukan juga kadar Hemoglobin yang normal dalam darah ibu. Konsumsi madu terbukti secara ilmiah dapat meningkatkan kadar Haemoglobin (Hb) (Bachtiar, 2020). Adapun fungsi $\mathrm{Hb}$ dalam darah yaitu mengikat oksigen $\left(\mathrm{O}_{2}\right)$, dimana oksigen sangat dibutuhkan untuk kekuatan kontraksi/his pada persalinan kala I yang berperan terhadap kemajuan pembukaan jalan lahir, sehingga bila pembukaan jalan lahir dapat berlangsung dengan cepat berdampak terhadap pengurangan waktu pada persalinan kala I. Salah satu faktor yang mempengaruhi proses persalinan yaitu Power (Kekuatan), kekuatan terdiri dari kemampuan ibu melakukan kontraksi primer dan kontraksi sekunder. Kontraksi primer membuat serviks menipis (effacement) dan dilatasi yang menyebabkan penurunan janin. Apabila kontraksi/his pada persalinan kala I kurang efektif dapat mengganggu proses penurunan bayi ke jalan lahir sehingga berdampak terhadap lamanya persalinan kala I.

Sepanjang kehamilan ibu dianjurkan untuk menjaga pola makan yang bergizi, karena melahirkan merupakan proses yang berat yang membutuhkan energi dan stamina (Praditama, 2014). Salah satu zat makanan yang dapat menambah energi yaitu madu yang memiiki kandungan berupa senyawa fruktosa, glukosa, maltosa, sukrosa dan karbohidrat lainnya. Selain itu juga madu merupakan anti oksidan yang berfungsi membantu melinungi tubuh dari infeksi, mencegah kerusakan sel, hingga membantu produksi kolagen yang berfungsi untuk melekatkan tulang dengan otot.

Saat-saat menjelang persalinan merupakan saat yang cukup mendebarkan bagi seorang ibu dan keluarganya, oleh karena itu dilakukan persiapan yang harus dilakukan maksimal melalui asupan zat gizi atau vitamin yang mampu mendukung lancarnya persalinan. Dalam rangka mendukung persalinan yang lancar juga bisa diusahakan dengan memilih bahan makanan yang merupakan sumber zat gizi atau vitamin tertentu. Beberapa jenis vitamin dapat memberikan manfaat yang optimal dalam mendukung lancarnya persalinan dengan memberikan suplay energi yang baik serta dukungan dengan mengoptimalisasi fungsi sel dan organ.

Madu merupakan bahan makanan cair yang mudah diserap oleh tubuh dapat bereaksi langsung dalam menghasilkan tenaga. Proses alami dalam tubuh bahwa dalam madu terdapat kandungan vitamin, mineral, protein, asam lemak serta zat penting lainnya yang dapat menunjang energi dalam tubuh yang berdampak terhadap penambahan tenaga yang diperlukan untuk kekuatan kontraksi uterus.

Pemberian madu pada masa kehamilan bisa langsung diminum tanpa diberi air, namun pada persalinan sebaiknya pemberian madu diencerkan dulu dengan menggunakan air hangat agar dapat membantu proses penyerapan oleh tubuh dan dapat menghasilkan tenaga. Manfaat madu pada menjelang persalinan berfungsi sebagai suplemen penambah tenaga yang diperlukan sebagai tenaga ekstra untuk mengejan pada proses persalinan.

Berdasarkan hasil penelitian bahwa konsumsi madu dapat mempengaruhi lamanya persalinan kala I, dalam hal ini mengurangi lamanya waktu pembukaan jalan lahir mulai dari belum ada pembukaan sampai dengan lengkap $(10 \mathrm{~cm})$. Secara normal pada persalinan kala I pada multigravida menurut Manuaba (2010) berdasarkan kurva Friedman, bahwa pada multigravida pembukaan jalan lahir setiap 1 jam 
jalan lahir dapat membuka sebesar $2 \mathrm{~cm}$ sehingga untuk menjadi $10 \mathrm{~cm}$ memerlukan waktu 5 jam. Oleh karena itu dianjurkan pada ibu hamil sebaiknya untuk mengkonsumsi madu pada masa kehamilannya dalam rangka persiapan tenaga yang diperlukan pada proses persalinan. Atas dasar tersebut, penulis menyarankan kepada tenaga kesehatan terutama bidan dan perawat untuk menganjurkan kepada ibu hamil mengkonsumsi madu sebanyak 2-3 sendok makan dua kali sehari karena madu dapat meningkatkan $\mathrm{Hb}$ pada ibu hamil dimana kadar $\mathrm{Hb}$ ini sangat berperan dalam kontraksi atau his yang diperlukan pada saat persalinan kala I untuk membantu dalam proses pembukaan jalan lahir.

\section{Pengaruh Madu terhadap Lama Persalinan Kala II}

Berdasarkan hasil penelitian didapatkan dari 30 orang responden yang konsumsi madu, lamanya persalinan kala II kurang dari atau sama dengan 30 menit sejumlah $70 \%$, sedangkan yang tidak konsumsi madu didapatkan lamanya persalinan kala II kurang dari atau sama dengan 30 menit sejumlah $40 \%$. Pada hasil uji Chi Square, didapatkan $p$-value $=0,02 \leq \alpha=0,05$ yang artinya ada pengaruh pemberian konsumsi madu pada ibu hamil multigravida trimester III terhadap lama persalinan kala II.

Hal ini mendukung hasil penelitian Zuliyanti (2012) dan penelitian Isriani (2017), yang penelitian keduanya menyatakan bahwa madu dapat berpengaruh terhadap lamanya persalinan kala I dan kala II. Pada penelitian Zuliyanti (2012), penelitian dilakukan dengan memberikan susu dan madu pada ibu bersalin terhadap lamanya kala I dan kala II, dengan hasil ada pengaruh pemberian susu dan madu terhadap lamanya kala II dengan $p$ value 0,001 . Sedangkan penelitian Isriani (2017) melakukan penelitian dengan memberikan kacang hijau dan madu terhadap lamanya kala II dengan $p$-value 0,000 .

Peneliti melakukan penelitian hanya dengan memberikan madu saja terhadap lamanya persalinan kala I dan kala II dan pengaruhnya tidak terlalu signifikan terhadap lamanya persalinan kala I dengan p-value 0,05 dan lamanya persalinan kala II dengan p-value 0,02. Berdasarkan hasil penelitian didapatkan bahwa pemberian madu dapat membantu proses persalinan kala II. Hasil penelitian ini bila dibandingkan dengan penelitian Zuliyanti (2012) dan penelitian Isriani (2017) bahwa pemberian madu saja pengaruhnya kurang maksimal bila dibandingkan dengan pemberian madu ditambah susu atau kacang hijau.
Salah satu faktor yang mempengaruhi proses persalinan yaitu Power (Kekuatan), kekuatan terdiri dari kemampuan ibu melakukan kontraksi primer yang membuat serviks menipis (effacement) dan dilatasi yang menyebabkan penurunan janin dan kontraksi sekunder yang diperlukan pada proses mengejan/mendorong janin keluar dari jalan lahir (dilahirkan). Kekuatan sekunder berupa dorongan ingin meneran dari ibu yang sangat tergantung dari kondisi fisik ibu. Apabila ibu lelah yang disebabkan karena asupan nutrisi yang kurang, hal ini dapat mengganggu proses kekuatan mengejan ibu yang kurang maksimal sehingga berdampak terhadap lamanya persalinan kala II.

Dampak dari persalinan kala II yang lama dapat membahayakan ibu dan janinnya. Pada ibu dapat menyebabkan terjadinya kelelahan sehingga ibu tidak mampu untuk mengejan dan menghambat proses kelahiran bayi. Dampak pada bayi, dapat mengakibatkan bayi lama di jalan lahir sehingga terjadi kompresi pada kepala bayi oleh panggul ibu yang mengakibatkan suplay darah ke kepala bayi berkurang sehingga terjadi terjadi kekurangan oksigen pada otak bayi yang dapat menyebabkan bayi mengalami aspiksia yang merupakan salah satu penyebab tingginya angka kematian bayi baru lahir.

Pada proses persalinan kala II yang dimulai dari pembukaan lengkap $(10 \mathrm{~cm})$ sampai bayi lahir, selain kontraksi/his yang akan berperan dalam proses pengeluaran bayi dari jalan lahir diperlukan juga kekuatan tenaga ibu mengedan. Menjelang persalinan ibu hamil dituntut untuk memiiki tenaga yang ekstra untuk mengejan. Oleh karena itu untuk menambah tenaga selama proses persalinan, ibu bersalin disarankan untuk konsumsi madu sebagai suplemen penambah tenaga yang dicampur dengan air hangat agar proses penyerapannya dapat cepat dan diubah sebagai energi untuk menambah tenaga yang diperlukan dalam proses mengedan.

Madu bermanfaat sebagai sumber kalori karena kandungan sukrosa dan kandungan karbohidrat kompleks serta kandungan senyawa lain yang penting seperti vitamin. Suranto (2004) menyatakan bahwa madu berkhasiat untuk menghasilkan energi, meningkatkan daya tahan tubuh dan meningkatkan stamina. Madu juga mengandung unsur makanan yang luar biasa walaupun kadarnya kecil, sehingga bisa digunakan sebagai tonik alami (Baskhara, 2008). Manfaat madu bukan hanya sekedar untuk kesehatan karena pada dasarnya madu merupakan bahan makanan yang populer didunia kuliner sebagai pemanis atau pengental. Kandungan yang 
terdapat di dalam madu berupa Maltosa, sukrosa dan karbohidrat kompleks lainnya. Kandungan yang lainnya pada madu berupa anti-oksidan meskipun hanya sedikit yakni dari senyawa Chrysin, Pinobanksim, vitamin C, katalase dan Pinocembrin. Komposisi kompleks inilah yang membuat manfaat madu baik untuk kesehatan.

Ibu bersalin kala II sangat disarankan untuk mengkonsumsi madu dalam rangka untuk menambah tenaga karena ibu bersalin butuh tenaga ekstra yang diperlukan dalam proses melahirkan bayi. Manfaat madu bagi ibu hamil yang menjelang persalinan terutama berkaitan dengan menambah tenaga yang sangat berperan dalam kekuatan kontraksi (his) yang sangat diperlukan dalam proses persalinan. Pada proses persalinan diperlukan tenaga terutama his untuk mendorong janin agar dapat membantu pembukaan jalan lahir sehingga proses persalinan dapat berlangsung secara normal.

Berdasarkan hasil penelitian bahwa konsumsi madu dapat mempengaruhi lamanya persalinan kala II, dalam hal ini mengurangi lamanya waktu dalam proses kelahiran bayi. Secara normal pada persalinan kala II pada multigravida menurut Manuaba (2010) berdasarkan kurve Friedman, bahwa pada multigravida proses melahirkan bayi memerlukan waktu kurang dari 30 menit. Oleh karena itu dianjurkan pada ibu bersalin sebaiknya untuk

\section{DAFTAR PUSTAKA}

Bachtiar, A. H., Bukhari, A., \& Hadju, V. (2020). Efek Pemberian Madu Pada Ibu Hamil Anemia Terhadap Kadar MDA, 8ohdg dan Hemoglobin. Quality: Kesehatan, 14(1), 53-59.

Jurnal

Badan Pusat Statistik. (2017). Survey Demografi Kesehatan Indonesia (SDKI) 2017. Jakarta: Badan Pusat Statistik.

Baskhara, A. L., (2008). Khasiat Keajaiban Madu untuk Kesehatan \& Kecantikan, Yogyakarta: Smile-Book.

Dinas Kesehatan Kabupaten Lampung Selatan. (2017). Profil Dinkes Kabupaten Lampung Selatan. Lampung Selatan.

Dinas Kesehatan Provinsi Lampung. (2016). Profil Dinkes Provinsi Lampung 2016. Bandar Lampung.

Hidayat, A. A. (2007). Metode Penelitian Kebidanan Dan Analisa Data. Jakarta: Salemba Medika.

Ihsan, A. A. (2011). Terapi Madu Hidup Sehat Ala Rasulullah. Jogyakarta: Javalitera. mengkonsumsi madu pada masa persalinannya dalam rangka persiapan tenaga ekstra yang diperlukan pada proses mengejan. Atas dasar tersebut, penulis menyarankan kepada tenaga kesehatan terutama bidan dan perawat untuk menganjurkan kepada ibu hamil mengkonsumsi madu sebanyak 2-3 sendok makan dua kali sehari yang cara konsumsinya dicampur dengan air hangat agar proses penyerapan dalam tubuh lebih efektif dan diminum saat dalam keadaan relaksasi/tidak ada kontraksi. Madu merupakan suplemen penambah tenaga yang sangat berperan dalam proses mengejan pada saat persalinan kala II untuk membantu dalam proses mendorong bayi keluar dari jalan lahir.

\section{SIMPULAN}

Ada pengaruh konsumsi madu terhadap lama persalinan kala I dan ada pengaruh konsumsi madu terhadap lama persalinan kala II. Hasil penelitian ini dapat menjadi acuan bagi bidan yang memberikan pelayanan kepada ibu hamil dan ibu bersalin untuk menganjurkan kepada ibu agar mengkonsumsi madu 2-3 sendok makan 2 kali dalam sehari untuk menambah kontraksi uterus dan kekuatan mengedan pada proses persalinan.
Kusumahati, (2010). Asuhan Kebidanan Nifas. Yogyakarta: Andi.

Manuaba, I. B. G. (2010). Ilmu Kebidanan, Penyakit Kandungan Dan Keluarga Berencana. Jakarta: EGC.

Isriyani, Popy. (2017). Pengaruh Pemberian Kacang Hijau Dan Madu Pada Ibu Bersalin Terhadap Lamanya Kala II Di Wilayah Kerja Puskesmas Situjuh Kecamatan Situjuah Limo Nagari Kabupaten Lima Puluah Kota. Laporan Tugas Akhir. Bukit Tinggi: Universitas Fort de Kock.

Praditama, A. D. (2014). Pola Makan pada Ibu Hamil dan Pasca Melahirkan di Desa Tiripan Kecamatan Berbek Kabupaten Nganjuk. [Skripsi]. Surabaya: Fakultas Ilmu Sosial dan Ilmu Politik, Universitas Airlangga.

Purbaya, J. R. (2007). Mengenal dan memanfaatkan khasiat madu alami. Bandung: Pinonir Jaya. 
Sambodo, N.W., (2009). Uji Efek Tonik Madu Rambutan Pada Mencit Putih Jantan Dengan Metode Natatory Exhaustion. [Skripsi]. Surakarta: Fakultas Farmasi, Universitas Muhammadiyah Surakarta.

Suroso, S., \& Paryono, P. (2016). Pengaruh konsumsi sari kurma pada akhir kehamilan terhadap kemajuan persalinan Kala I dan jumlah perdarahan saat persalinan pada primipara di wilayah kerja Puskesmas Klaten Selatan. Interest: Jurnal Ilmu Kesehatan, 5(1), 41-45.
Suranto, Adji S. (2004). Khasiat \& Manfaat Madu Herbal. AgroMedia.

World Health Organization. (2019). Trends In Maternal Mortality 2000 to 2017: estimates by WHO, UNICEF, UNFPA, World Bank Group and the United Nations Population Division.

Zuliyanti, N. I. (2012). Pengaruh pemberian susu dan madu pada ibu intranatal terhadap Lamanya kala II di rumah bersalin kharisma husada kartasura Sukoharjo. Jurnal Komunikasi Kesehatan, 1(01). 